\title{
EIF4G1 wt Allele
}

National Cancer Institute

\section{Source}

National Cancer Institute. ElF4G1 wt Allele. NCI Thesaurus. Code C82962.

Human EIF4G1 wild-type allele is located within 3q27-qter and is approximately $21 \mathrm{~kb}$ in length. This allele, which encodes eukaryotic translation initiation factor 4 gamma 1 protein, plays a role in recognition by and recruitment of mRNA to the ribosome. 